\title{
Hubungan Konsumsi Makanan Sumber Antioksidan dan Omega-3 Terhadap Tekanan Darah Masyarakat di Sumatera Barat
}

\author{
Harris Putra Reza ${ }^{1}$, Nur Indrawati Lipoeto ${ }^{2}$, Husnil Kadri ${ }^{3}$
}

\begin{abstract}
Abstrak
Pengaturan tekanan darah melibatkan banyak sistem seperti endotelium melalui aktifitas nitrit oksida. Produksi dan aktivitas nitrit oksida dapat dipengaruhi oleh pola makan, terutama asupan makanan sumber antioksidan dan omega-3. Tujuan penelitian ini adalah menentukan hubungan antara makanan sumber antioksidan dan omega-3 terhadap tekanan darah masyarakat di Sumatera barat. Penelitian ini merupakan penelitian dengan data sekunder yang berasal dari penelitian Lipoeto et al (2008) yaitu "Faktor Determinan Hipertensi di Sumatera Barat". Subyek penelitian berjumlah 400 orang yang diwawancarai menggunakan formulir Food Frequency Questioner (FFQ) dan pemeriksaan tekanan darah dengan sphygmomanometer air raksa. Penelitian ini dilaksanakan dari Maret sampai Mei 2014. Hasil penelitian menunjukkan bahwa rerata konsumsi sayur dan buah masyarakat di Sumatera Barat lebih tinggi dari rerata Internasional, tapi lebih rendah dari rerata nasional dengan rerata $200.7 \pm 128.11$ gram/orang/hari, rerata konsumsi ikan masyarakat di Sumatera Barat lebih tinggi dari rerata nasional dan internasional yakni $101.26 \pm 62.18$ gram/orang/hari. Prevalensi hipertensi di Sumatera Barat mengalami kenaikan menjadi sebesar $41.76 \%$. Tingkat konsumsi makanan sumber antioksidan dan omega-3 masyarakat Sumatera Barat lebih tinggi daripada rerata internasional. Terjadi peningkatan prevalensi hipertensi di Sumatera Barat. Kesimpulan hasil studi ini adalah tidak terdapat hubungan antara konsumsi makanan sumber antioksidan dan omega-3 terhadap tekanan darah.
\end{abstract}

Kata kunci: antioksidan, omega-3, tekanan darah

\begin{abstract}
Blood pressure regulation involves many systems, one of the most important is endothelial system through nitric oxide activity. Nitric oxide is also known to be affected by diet, especially dietary intake of antioxidants and omega-3. The objective of this study was to determine the correlation between consumption of food source of antioxidant and omega-3 on blood pressure to people in West Sumatra. This study used secondary data from research by Lipoeto et al (2008) in "Determinant Factors of Hypertension in West Sumatra". Subjects were 400 people who were interviewed using Food Frequency Questionnaire (FFQ) form and examination of blood pressure using mercury sphygmomanometer. This research was conducted from March to May 2014. The result showed that the average consumption of vegetables and fruits of West Sumatran people is higher than international average, but lower than national average with a mean of $200.7 \pm 128.11 \mathrm{~g} /$ person / day, the average consumption of fish of West Sumatran people is higher than the national and international average ie, $101.26 \pm 62.18 \mathrm{~g} /$ person / day. The prevalence of hypertension in West Sumatra was increased to $41.76 \%$. This study obtained the level of consumption of food sources of antioxidants and omega-3 of West Sumatran people is higher than international average. There is prevalence increasing of hypertension in West Sumatra. The conclusion is no correlation between the consumption of food sources of antioxidants and omega-3 on blood pressure.
\end{abstract}

Keywords: antioxidant, omega-3, blood pressure 
Affiliasi penulis: 1. Pendidikan Dokter FK UNAND (Fakultas Kedokteran Universitas Andalas Padang), 2. Bagian Gizi FK UNAND 3. Bagian Biokimia FK UNAND

Korespondensi: Harris Putra Reza, Email:

harrisputrareza@ymail.com, Telp: 081374137946

\section{PENDAHULUAN}

Hipertensi masih menjadi masalah kesehatan dengan prevalensi yang terus meningkat, di dunia maupun di Sumatera Barat. Menurut WHO dan the International Society of Hypertension (ISH), pada tahun 2003 terdapat 600 juta penderita hipertensi di seluruh dunia, dan 3 juta di antaranya meninggal setiap tahunnya. ${ }^{1}$ Hasil Riskesdas tahun 2007 di Indonesia prevalensi hipertensi 32,2\%. ${ }^{2}$ Selain itu, hasil Riskesdas juga menunjukkan hipertensi menduduki peringkat ketiga penyebab kematian utama untuk semua kelompok umur di Indonesia dengan Case Fatality Rate (CFR) 6,8\%. ${ }^{2}$ Prevalensi hipertensi di Sumatera Barat juga cenderung meningkat. Hasil riset kesehatan dasar yang dilakukan departemen kesehatan RI tahun 2007, prevalensi hipertensi di Sumatera Barat sudah mencapai $31,2 \%{ }^{2}$

Paradigma tentang pengaturan tekanan darah sendiri kini telah bergeser dari yang diregulasi oleh otak dan ginjal ke salah satu organ terluas dalam tubuh yaitu endotelium. Endotel pembuluh darah dapat memproduksi relaxing factor yang mempunyai karakteristik sebagai vasoaktif nitrit oksida (NO) dan zat ini dapat mengatur tonus vaskuler. Aktivitas NO di sel endotel dan sekitarnya menyebabkan terjadinya relaksasi otot polos vaskuler sehingga terjadi vasodilatasi. ${ }^{3}$

NO diketahui dapat dipengaruhi kadarnya oleh pola makan. Beberapa zat gizi dapat mengatur kadar NO plasma. Antioksidan vitamin A, vitamin C, vitamin $\mathrm{E}$ dan flavonoid meningkatkan sintesis $\mathrm{NO}$ sedangkan diet tinggi omega tiga dapat memperbaiki sintesis $\mathrm{NO}^{3}$

Antioksidan secara umum dapat meningkatkan produksi NO melalui dua cara. Pertama: dengan meningkatkan ekspresi protein mRNA dan Endotelial NO Syntase (eNOS) yang kemudian meningkatkan aktivitas NO Sintase. Kedua: antioksidan juga melindungi NO yang telah disintesis dari oksidasi. Kedua hal tersebut dapat memperpanjang usia NO dan meningkatkan efeknya. ${ }^{4}$ Dari berbagai penelitian didapati sayur dan buah merupakan sumber utama antioksidan yang berasal dari luar tubuh. ${ }^{5}$ Tingkat konsumsi buah dan sayur masyarakat Sumatera Barat juga masuk dalam kategori mengkhawatirkan. Menurut hasil Riset Kesehatan dasar oleh Departemen Kesehatan Republik Indonesia pada tahun 2007, prevalensi kurang makan buah dan sayur masyarakat Sumatera Barat mencapai 97,8\%, tertinggi kedua setelah Riau. ${ }^{2}$ Oleh karena itu, penelitian ini menggunakan tingkat konsumsi sayur dan buah sebagai standar tingkat konsumsi antioksidan.

Asam lemak omega-3 juga memiliki peran penting dalam mengendalikan tekanan darah. Asam lemak omega-3 merupakan senyawa vasodilator yang kuat yang mampu mengembangkan pembuluh darah. Asam lemak omega-3 juga membantu menghentikan penggumpalan darah. ${ }^{6}$ Perannya ini mulai banyak diteliti setelah pengamatan rendahnya angka penyakit kardiovaskuler pada penduduk Eskimo dan Jepang dengan pola makan tinggi ikan. ${ }^{7}$ Dari 14 studi kohor yang telah dilakukan, 12 menyimpulkan adanya pengaruh menguntungkan dari omega-3 terhadap penyakit kardiovaskular dan menyimpulkan tidak terdapat hubungan. ${ }^{8}$ Hipotesis mengenai mekanisme omega-3 menurunkan tekanan darah adalah melalui perubahan keseimbangan vasoaktif prostaglandin, menekan produksi vasokonstriktor tromboksan, dan meningkatkan produksi vasodilator prostasiklin. ${ }^{7}$ Menurut studi eksperimental, omega-3 juga memiliki manfaat sebagai anti-platelet agregasi dengan menurunkan produksi tromboksan A2. ${ }^{7}$ Asam lemak omega-3 paling banyak ditemukan pada ikan. ${ }^{9}$ Tingkat konsumsi ikan masyarakat Sumatera Barat masih rendah, sekitar 30,6 kg/kapita/tahun dibawah standar nasional sebesar 33,9 kg/kapita/tahun. ${ }^{10}$

Berdasarkan uraian di atas, perlu dilakukan penelitian mengenai hubungan konsumsi makanan sumber antioksidan dan omega-3 terhadap tekanan darah masyarakat di Sumatera Barat. 


\section{METODE}

Penelitian ini menggunakan data sekunder dari penelitian Lipoeto et al (2008) dalam "Faktor Determinan Hipertensi di Sumatera Barat". Populasi penelitian adalah masyarakat Sumatera Barat yang berjumlah 4.800 .000 jiwa. $^{11}$ Jumlah sampel sebanyak 400 orang yang memenuhi kriteria inklusi yaitu; berusia 17 tahun ke atas, bersedia diwawancarai oleh petugas dan bisa berkomunikasi dengan baik. Kriteria eksklusi adalah; orang yang tidak hadir pada saat yang ditentukan dan penderita penyakit kronis atas diagnosis dokter. Data yang diperoleh diolah dengan software komputer dan analisis hasil penelitian dilakukan uji perbedaan dengan tingkat kemaknaan $p<0,05$.

\section{HASIL}

Data subyek berasal dari penelitian yang dilakukan di dua kabupaten/kota di Sumatera Barat, yaitu Kotamadya Solok dan Kabupaten Pesisir Selatan dengan jumlah subyek penelitian adalah 400 orang yang setelah dilakukan proses cleaning, terbuang 10 subyek penelitian, sehingga total subjek penelitian yang datanya dioleh adalah sebanyak 390 orang (Tabel 1).

Tabel 1. Karakteristik subyek penelitian

\begin{tabular}{lc}
\hline Karakteristik Subyek Penelitian & N (\%) \\
\hline Pria & $136(34.9 \%)$ \\
Wanita & $254(65.1 \%)$ \\
Total & $390(100 \%)$ \\
\hline
\end{tabular}

Tingkat konsumsi sayur dan buah responden diukur dengan wawancara menggunakan formulir FFQ dengan bantuan food model dan didapatkan rata-rata konsumsi sayur dan buah masyarakat Sumatera Barat adalah $200.7 \pm 128.11$ gr/orang/hari (Tabel 2). Tingkat konsumsi ikan responden diukur dengan wawancara menggunakan formulir FFQ dengan bantuan food model dan didapatkan ratarata konsumsi ikan masyarakat Sumatera Barat dari penelitian ini adalah $101.26 \pm 62.18$ gram/orang/hari (Tabel 2).
Tabel 2. Tingkat konsumsi sayur dan buah masyarakat Sumatera Barat

\begin{tabular}{|c|c|c|c|c|}
\hline $\begin{array}{l}\text { (gram/orang/ } \\
\text { hari) }\end{array}$ & $\begin{array}{l}\text { Rata- } \\
\text { rata }\end{array}$ & SD & $\begin{array}{c}\text { Nilai } \\
\text { Terendah }\end{array}$ & $\begin{array}{c}\text { Nilai } \\
\text { Tertinggi }\end{array}$ \\
\hline Sayur dan & 200.70 & 128.11 & 11.5 & 978.7 \\
\hline \multicolumn{5}{|l|}{ Buah } \\
\hline ikan & 101.26 & 62.18 & 7.1 & 608.3 \\
\hline
\end{tabular}

Sphygmomanometer air raksa, sehingga didapatkan mayoritas responden memiliki tekanan darah yang normal, yakni 227 dari 390 (58.21\%). Rata-rata tekanan darah sistolik responden adalah sebesar $125.92 \pm 17.47 \mathrm{mmHg}$ dengan rata-rata tekanan darah diastolik sebesar $85.56 \pm 12.5 \mathrm{mmHg}$. Berdasarkan jenis kelamin, didapatkan prevalensi hipertensi pada laki-laki sebesar $44.85 \%$, lebih tinggi daripada prevalensi hipertensi pada perempuan, yaitu sebesar 40.16\%. Rata-rata tekanan darah sistolik dan diastolik pada laki-laki lebih rendah daripada perempuan.

Prevalensi hipertensi tertinggi ada pada tingkatan usia $>65$ tahun, sebesar $71.88 \%$ dengan prevalensi hipertensi terendah terdapat pada tingkat usia 26-35 tahun yaitu sebesar $21.69 \%$. Rata-rata tekanan darah sistolik tertinggi terdapat pada tingkat usia >65 tahun, yaitu $139.97 \pm 19.68 \mathrm{mmHg}$ dan rata-rata tekanan darah diastolik tertinggi terdapat pada tingkat usia 56-65 tahun yaitu sebesar $90 \pm$ $11.64 \mathrm{mmHg}$.

Tabel 3. Tingkat tekanan darah masyarakat Sumatera Barat.

\begin{tabular}{ccccc}
\hline & $\begin{array}{c}\text { Hiper- } \\
\text { tensi }\end{array}$ & $\begin{array}{c}\text { Normo- } \\
\text { tensi }\end{array}$ & $\begin{array}{c}\text { TD } \\
\text { sist. }\end{array}$ & $\begin{array}{c}\text { TD } \\
\text { diast. }\end{array}$ \\
\hline umum & 163 & 227 & $125.92 \pm$ & $85.56 \pm$ \\
& $(41.79 \%)$ & $(58.21 \%)$ & 17.47 & 12.5 \\
\hline
\end{tabular}

Pada analisis data disimpulkan bahwa tidak terdapat hubungan antara konsumsi makanan sumber antioksidan dan omega-3 dengan tekanan darah sistolik maupun tekanan darah diastolik, karena $p>0.05$. 
Tabel 5. Hasil analisis data hubungan konsumsi makanan sumber antioksidan dan omega-3 dengan tekanan darah

\begin{tabular}{lll}
\hline & $\begin{array}{c}\text { Tekanan Darah } \\
\text { Sistolik }\end{array}$ & $\begin{array}{c}\text { Tekanan Darah } \\
\text { Diastolik }\end{array}$ \\
\hline Antioksidan & $r=-0.044$ & $r=-0.005$ \\
& $p=0.390$ & $p=0.923$ \\
\hline Omega-3 & $r=0.022$ & $r=0.014$ \\
& $P=0.666$ & $p=0.789$ \\
\hline
\end{tabular}

\section{PEMBAHASAN}

\section{Keterbatasan Penelitian}

Penelitian tentang hubungan makanan sumber antioksidan dan omega-3 dengan tekanan darah masyarakat di Sumatera barat dengan menggunakan data penelitian Nur Indrawati Lipoeto ini telah dilakukan sesuai prosedur pengolahan data yang meliputi editing, coding, entry dan cleaning data dan analisis data. Keterbatasan dalam penelitian ini adalah metode cross-sectional yang digunakan dalam penelitian ini menyebabkan hasil yang berbeda dengan penelitian sebelumnya.

\section{Tingkat Konsumsi Makanan Sumber Antioksidan}

Responden pada penelitian ini berusia antara 18-90 tahun dengan rata-rata 40,93 \pm 0.8 tahun. Didapatkan rata-rata konsumsi sayur dan buah masyarakat Sumatera barat sebesar $200.7 \pm$ 128.11 gram/orang/hari. Menurut FAO, rata-rata konsumsi sayur dan buah masyarakat dunia saat ini adalah sebesar 180 gram/orang/hari. ${ }^{12}$ Hasil pada penelitian ini menunjukkan tingkat konsumsi sayur dan buah masyarakat Sumatera Barat sudah diatas rata-rata Internasional yaitu sebesar $200.7 \pm 128.11$ gram/orang/hari.

Tingkat konsumsi sayur dan buah per kapita masyarakat Indonesia mencapai 205.21 gram/ orang/hari, sedikit lebih tinggi dari hasil penelitian ini, yakni $200.7 \pm 128.11$ gram/orang/hari. Rata-rata konsumsi sayur dan buah responden pada penelitian ini juga masih lebih kecil dibandingkan dengan penduduk negara-negara lain seperti Singapura dan Vietnam yang telah mencapai lebih dari 274 gram/orang/hari. ${ }^{13}$

\section{Tingkat Konsumsi Makanan Sumber Omega-3}

Tingkat konsumsi ikan rata-rata masyarakat mencapai $101.26 \pm 62.18$ gr/orang/hari. Menurut $\mathrm{FAO}$, rata-rata konsumsi ikan masyarakat dunia saat ini adalah sebesar 84.93 gram/orang/hari. ${ }^{14}$ Hasil pada penelitian ini menunjukkan tingkat konsumsi ikan masyarakat Sumatera Barat sudah di atas rata-rata Internasional yaitu sebesar $101.26 \pm$ $62.18 \mathrm{gr} /$ orang/hari.

Tingkat konsumsi ikan per kapita masyarakat Indonesia mencapai 95.89 gram/orang/hari. Hasil penelitian ini juga masih lebih tinggi yaitu $101.26 \pm$ 62.18 gr/orang/hari. ${ }^{15}$ Di Sumatera Barat, tingkat konsumsi ikan per kapita masyarakat Sumatera Barat adalah 87.67 gram/orang/hari. Penelitian ini mendapati hasil yang lebih tinggi, yakni sebesar $101.26 \pm 62.18$ gr/orang/hari. ${ }^{13}$

\section{Tingkat Tekanan darah Masyarakat Sumatera Barat}

Prevalensi hipertensi masyarakat Sumatera barat adalah sebesar $22.6 \%{ }^{16}$ Hasil penelitian ini mendapati data prevalensi yang lebih besar dari prevalensi nasional maupun provinsi yakni $41.79 \%$.

Prevalensi hipertensi yang lebih besar pada penelitian ini dimungkinkan terjadi karena responden didominasi oleh penduduk berusia 40 tahun ke atas dengan rata-rata usia responden yang mencapai 40,93 \pm 0.8 tahun. Resiko hipertensi meningkat seiring meningkatnya usia. Dilaporkan bahwa resiko hipertensi pada usia 40 tahun ke atas meningkat 2,47 hingga 11,53 kali lipat dibandingkan penduduk yang berusia 18-34 tahun. ${ }^{17}$

Pada penelitian lain, Sulastri danLipoeto juga melaporkan bahwa terdapat hubungan positif bermakna antara konsumsi antioksidan (vitamin E) dengan kadar NO plasma pada subjek hipertensi dengan alel heterozigot TC $(p=0,03) .{ }^{18}$

Didapatkan 58.21\% $\quad(n=227)$ responden memiliki tekanan darah yang normal dan $41.79 \%$ $(n=163)$ responden memiliki tekanan darah tinggi. Hasil ini lebih besar dari prevalensi nasional hipertensi dimana tingkat hipertensi masyarakat Indonesia hanya sebesar $25.8 \%{ }^{19}$ 


\section{Hubungan Konsumsi Makanan Sumber Antioksidan dengan Tekanan Darah}

Hasil analisis data penelitian ini menunjukkan bahwa tidak terdapat hubungan antara tingkat konsumsi makanan sumber antioksidan dengan tekanan darah. Hasil ini berbeda dari penelitian sebelumnya yang menemukan hubungan dengan korelasi negatif yang bermakna. Penelitian Lipoeto et al melaporkan bahwa terdapat perbedaan yang signifikan antara tekanan darah sistolik dan diastolik sebelum dan sesudah pemberian diet tinggi antioksidan dibanding diet rendah antioksidan. ${ }^{3}$ Responden yang diberi diet tinggi antioksidan mengalami penurunan tekanan darah sistolik dan diastolik yang lebih signifikan dibandingkan dengan responden yang diberi diet rendah antioksidan. Livius et al dalam penelitiannya melaporkan bahwa suplementasi antioksidan vitamin $\mathrm{C}$ jangka panjang secara bermakna meningkatkan aktivitas eNOS dan tidak mempengaruhi iNOS pada tikus normal, tetapi berpengaruh pada tikus defisiensi apo E. ${ }^{19}$

Perbedaan hasil penelitian ini dengan penelitian sebelumnya kemungkinan terjadi karena beberapa hal. Pertama, responden pada penelitian ini didominasi oleh penduduk yang berusia di atas 40 tahun dengan rata-rata usia mencapai 40,93 \pm 0.8 tahun. Penduduk yang berusia lanjut memiliki resiko hipertensi yang lebih besar, sehingga kemungkinan terkendalinya tekanan darah oleh asupan antioksidan menjadi lebih kecil. Kedua, penelitian ini juga tidak melibatkan variabel-variabel yang mempengaruhi hipertensi lainnya, seperti Indeks Massa Tubuh(IMT) yang cukup signifikan pengaruhnya terhadap tekanan darah, sehingga nilai tekanan darah dan korelasinya dapat menjadi bias dan tidak bermakna. Ketiga, Penelitian ini dilakukan dengan metode cross-sectional study tanpa intervensi terhadap responden, sementara penelitian sebelumnya dilakukaan dengan memberi intervensi terhadap responden penelitian.

\section{Hubungan Konsumsi Makanan Sumber Omega-3 dengan Tekanan Darah}

Hasil analisis statistik menunjukkan bahwa tidak terdapat hubungan antara tingkat konsumsi makanan sumber antioksidan dengan tekanan darah. Hasil ini berbeda dari penelitian yang dilakukan sebelumnya. Sebagian besar penelitian menemukan hubungan dengan korelasi negatif yang bermakna. Putri melaporkan bahwa terjadi penurunan tekanan darah sistolik sebesar 5.52 $\mathrm{mmHg}$ dan tekanan darah diastolik sebesar 6.04 $\mathrm{mmHg}$ setelah pemberian minyak ikan selama 2 minggu. ${ }^{6}$

Pada penelitian lain dikemukakan bahwa konsumsi minyak ikan dengan dosis 2-3 gram/hari dapat menurunkan tekanan darah sebesar 4.4 $\mathrm{mmHg}$ tekanan darah sistolik dan $6.4 \mathrm{mmHg}$ tekanan darah diastolik dan juga dapat menurunkan berat badan. ${ }^{20}$ Penelitian lain melaporkan bahwa pada subjek obese dengan hipertensi yang diberikan 3.4 gram minyak ikan terjadi penurunan tekanan darah sistolik sebesar $4.4 \mathrm{mmHg}$ dan tekanan darah diastolik sebesar $5.2 \mathrm{mmHg}$. Penelitian metaanalisis menunjukkan bahwa adanya penurunan tekanan darah sistolik/tekanan darah diastolik 0.66/0.35 mmHg tiap gram konsumsi minyak ikan pada hipertensi. ${ }^{6}$

Perbedaan hasil penelitian ini dengan penelitian sebelumnya kemungkinan terjadi karena beberapa hal. Pertama, responden pada penelitian ini didominasi oleh penduduk yang berusia di atas 40 tahun dengan rata-rata usia mencapai 40,93 \pm 0.8 tahun. Penduduk yang berusia lanjut memiliki resiko hipertensi yang lebih besar, sehingga kemungkinan terkendalinya tekanan darah oleh asupan omega-3 menjadi lebih kecil. Kedua, penelitian ini juga tidak melibatkan variabel yang mempengaruhi hipertensi, seperti Indeks Massa Tubuh (IMT) yang cukup signifikan pengaruhnya terhadap tekanan darah, sehingga nilai tekanan darah dan korelasinya dapat menjadi bias dan tidak bermakna. Ketiga, penelitian ini menggunakan konsumsi ikan sebagai indikator makanan sumber omega-3 tanpa menilai cara pengolahan ikan tersebut. Perbedaan dalam cara pengolahan ikan dapat memberikan efek yang berbeda terhadap tekanan darah. Keempat, penelitian ini dilakukan dengan metode cross-sectional tanpa intervensi terhadap responden, sementara penelitian sebelumnya dilakukan dengan intervensi. 


\section{KESIMPULAN}

Tingkat rata-rata konsumsi sayur dan buah masyarakat di Sumatera Barat lebih tinggi dari ratarata Internasional, tapi lebih rendah dari rata-rata nasional.

Tingkat rata-rata konsumsi ikan masyarakat di Sumatera Barat lebih tinggi dari rata-rata nasional dan internasional

Tidak terdapat hubungan antara tingkat konsumsi makanan sumber antioksidan dan omega3 dengan tekanan darah pada masyarakat di Sumatera Barat.

\section{DAFTAR PUSTAKA}

1. WHO-ISH Hypertension Guideline Committee. Guidelines of the management of hypertension. J Hypertension. 2003; 21(11):1983-92.

2. Departemen Kesehatan Republik Indonesia. Riset kesehatan dasar. Jakarta: Balai Penelitian dan Pengembangan Kesehatan Departemen Kesehatan RI; 2007.

3. Lipoeto NI, Rosalina L, Sulastri D. Pemberian diet Minangkabau tinggi sumber antioksidan dapat menurunkan tekanan darah. Padang: Universitas Andalas; 2008:1-12.

4. Kojsova S. The effect of different antioxidants on nitric oxide production in hypertensive rats. Physiol. Res. 2006;55(1):3-16.

5. Lubis SMI. Tingkat pengetahuan masyarakat tentang manfaat wortel sebagai sumber antioksidan alami untuk mencegah katarak (skripsi). Medan: Fakultas Kedokteran Universitas Sumatera Utara; 2010.

6. Putri WAK. Pengaruh pemberian minyak ikan terhadap tekanan darah wanita hipertensi (skripsi). Semarang: Fakultas Kedokteran Universitas Diponegoro; 2013.

7. Appel LJ, Miller ER, Seidler AJ, Whelton PK. Does suplementation of diet with fish oil reduce blood pressure?. Arch Intern Med.1993;153(12): 1429-38.

8. Breslow JL. Omega-3 fatty acids and cardiovascular disease. Symposium omega-3 fatty acid: recommendations for therapeuties and prevention. New York: Columbia University; 2005. hlm.3-16.
9. Smith WL. Anti-inflammatory effects of omega-3 fatty acid in fish oil linked to lowering of prostaglandin. Washington: Federation of American Societies for Experimental Biology; 2006: 235-57.

10. Prayitno NI. Konsumsi ikan rendah. 2012 (diunduh 9 Juni 2014). Tersedia dari: URL: HIPERLINK http://www.padangekspres.co.id/? news $=$ berita $\&$ id $=42081$

11. Prayitno I. Jumlah penduduk Sumatera Barat. 2013 (diunduh 25 Februari 2014). Tersedia dari: URL: HYPERLINK http://www.klikpositif.com/ news/read/806/gubernur-data-jumlah-penduduksumbar-membingungkan.html

12. Musanif J. Konsumsi hortikultura Indonesia di bawah standar FAO. 2012 (diunduh 9 Juni 2014). Tersedia dari: URL: HYPERLINK http://www.antaranews.com/berita/326881/konsu msi-hortikultura-indonesia-di-bawah-standar-fao

13. Witjaksono F. Konsumsi buah dan sayur di Indonesia ketinggalan dari negara tetangga. 2013 (diunduh 9 Juni 2014). Tersedia dari: URL: HYPERLINK http://health.detik.com/read/2013/ 06/28/190119/2287595/763/konsumsi-buah-dansayur-di-indonesia-ketinggalan-dari-negaratetangga

14. Widjaja S. Tanggal 21 November akan dirancang sebagai hari ikan nasional. 2013 (diunduh 9 Juni 2014). Tersedia dari: URL: HYPERLINK http://www.p2hp.kkp.go.id/beritatanggal-21-november-akan-dicanangkansebagai-hari-ikan-nasional.html\#ixzz34ITXxFin

15. Hutagalung SP. Konsumsi ikan orang Indonesia masih kalah dari Malaysia. 2013 (diunduh 9 Juni 2014). Tersedia dari: URL: HYPERLINK http://finance.detik.com/read/2014/02/20/112617 /2503126/4/konsumsi-ikan-orang-indonesiamasih-kalah-dari-malaysia

16. Departemen Kesehatan Republik Indonesia. Riset kesehatan dasar. Jakarta: Balai Penelitian dan Pengembangan Kesehatan Departemen Kesehatan RI; 2013: 88-90.

17. Rahajeng E, Tuminah S. Prevalensi hipertensi dan determinannya di Indonesia. Majalah Kedokteran Indonesia. 2009;59(12):580-7. 
18. Sulastri D, Lipoeto NI. Konsumsi antioksidan dan ekspresi gen eNOS3 alel -786T>C pada penderita hipertensi etnik minangkabau. MKB. 2011;43(1):1-9.

19. Livius VD, Milstien S, Richardson D, Smith L, Katusic ZS. Long term vitamin $\mathrm{C}$ treatment increases vascular tetrahydrobiopterin levels and nitric oxide synthase activity. Circ Res. 2003;92:88.

20. Vanschoonbael K, De Maat MPM, Heemskerk JWM. Fish oil consumption and reduction of arterial disease. 2003 (diunduh 9 Juni 2014). Tersedia dari: URL: HYPERLINK http://nutrition. highwire.org/content/133/3/657.full 